\title{
Kira jako (nie)obcy O protagoniście mangi Death Note Takeshi Obaty i Tsugumi Ohby
}

Kira as a (non-)stranger

On the protagonist of the Death Note manga series created by Takeshi Obata and Tsugumi Ohba

Abstract: The article analyzes the alienation of the main character of the manga series Death Note, who owns the Death Notebook referred to in the title. The said notebook allows to kill any person. Drawing upon the theses of Michel Foucault related to the rights of monarchs of bygone times to condemn individuals to death, and to ritualizing death itself, the author of the article shows Kira as a continuator of the said monarchs. The motif of death from the hands of another person is indicated as a form of revenge for harms suffered by one, based on considerations by Jean Baudrillard. The text also aims to show that comic books are not just entertainment for the masses, but can convey serious content instead.

Keywords: ambivalence, Baudrillard, Foucault, stranger

Problematyka swojskości i obcości jest przedmiotem licznych refleksji naukowych, politycznych czy społecznych ${ }^{1}$. Na styku różnych kultur i norm etycznych ludzie dostrzegają, że kwestie te różnią się od siebie. Są także nośnikami odmiennych zasad współżycia lub w inny sposób realizują to, jak społeczeństwo postrzega wydarzenia wewnątrz swojej zbiorowości. Obcy staje się wtedy istotny, gdyż pozwala jednostce określić samą siebie przez odniesie do danej grupy, kultury $^{2}$. Antagonizuje on także ludzkie postawy, ponieważ

1 Zob. M. Dąbrowski, 2001; G. Simmel, 2006; B. Waldenfels, 2002; F. Znaniecki, 1990.

${ }^{2}$ Należy jednak pamiętać, że obcość to przede wszystkim kategoria interpretacyjna i dopiero w jej ramach wykluczająca. 
„obcość" będzie zawsze wartościowana ujemnie. To też z kolei może ustawić „obcego" w pozycji wroga. Wrogość ta może być przejawiana w różnorodnych dziedzinach społecznej aktywności ludzi. Dostrzec można ją wszędzie tam, gdzie dochodzi do spotkania się opozycyjnych systemów wartości, która to opozycja przenika ludzkie działania, ukierunkowuje je i dynamizuje.

Grabias, 2013, s. 238

Kultura stanowi niezwykle istotny czynnik więziotwórczy, toteż pojawienie się obcego powoduje rozluźnienie tych relacji, destabilizację ładu, nieporządek, wręcz chaos. Zygmunt Bauman zauważa: „[...] swym istnieniem [obcy - J.D.] kwestionują nieprzenikalność granic i znieważają majestat ładu. Przeszkadzają temu, co państwo chce budować, i psują to, co już zbudowało. Są mętną plamą na obrazie, jaki państwo pragnęło uczynić kryształowo przejrzystym i czytelnym" (Bauman, 2000, s. 41).

Niniejszy tekst stanowi analizę Lighta Yagami, głównego bohatera mangi Death Note, w myśl Baumanowskiej interpretacji figury obcego, który podważa zastany porządek. W moim przekonaniu państwo i społeczeństwo są z sobą połączone. To pierwsze narzuca swoim obywatelom pewne zasady życia społecznego. Za ich złamanie mogą grozić sankcje karne. Dzięki ustalonym regułom państwo jest (w przekonaniu samego państwa) poukładane, a wytyczone granice są klarowne. Obcy dąży do negacji zastanych norm rządzących państwem i wskazuje społeczeństwu inną, jego zdaniem, lepszą drogę. Dlatego też państwo, broniąc swojego majestatu, może chcieć ścigać wroga, jakim dla niego stał się obcy. W przypadku omawianej mangi takim niszczycielem państwowego ładu byłby właśnie Kira. Czyny protagonisty zdobywają coraz większe poparcie społeczne, dlatego też zostawienie go samemu sobie byłoby niczym innym, jak pozwoleniem na zniszczenie tego, co zbudowało państwo i co uznaje ono za dobre. Stąd moje przekonanie, że Kira w pełni wpisuje się w wizję obcego, jaką przedstawił Bauman. Dodatkowo w analizie wykorzystane zostaną myśli Michela Foucaulta oraz Jeana Baudrillarda dotyczące władzy nad życiem i śmiercią. Pozwoli to pokazać, że opozycja swój - obcy może w odniesieniu do protagonisty ulec zatarciu.

\section{Ambiwalencja śmierci}

Fabuła mangi opowiada historię wspomnianego Lighta Yagami, który zostaje właścicielem notesu śmierci należącego do jednego z Bogów Śmierci, Ryuka. Notes jest narzędziem służącym do zabijania, znajdują się w nim zasady, według których właściciel powinien postępować. Główna reguła mówi wyraźnie, iż osoba, której imię i nazwisko zostanie w nim zapisane, umrze. Śmierć, jeśli nie poda się przyczyn, następuje po czterdziestu sekundach w wyniku za- 
wału. Notes nie będzie działał w przypadku, gdy piszący nie wyobrazi sobie wyglądu człowieka, którego ma zamiar zabić. Dodatkowo notes pozwala na dowolne manipulowanie czasem i okolicznościami śmierci takiej osoby. Na skutek przejęcia boskiej mocy Light przyjmuje pseudonim Kira i od tej pory postanawia oczyścić świat $\mathrm{z}$ wszelkiej niegodziwości ${ }^{3}$. W ten sposób powstaje nowa sytuacja, w której społeczeństwo dzieli się na dwie frakcje: jedni stają po stronie samozwańczego boga, inni pragną go odnaleźć i zniszczyć.

Cały konflikt pomiędzy Kirą a ścigającymi go ludźmi jawi się jako walka z prawem, które reprezentuje, prawem dawnych władców, mogących dzięki swej mocy skazywać ludzi na śmierć. W czasach nam współczesnych tego typu osoba jest postrzegana w sposób jednoznacznie negatywny, ponieważ panująca biopolityka odwróciła cały motyw sprawowania kontroli. Obecnie rządy, zamiast skazywać na śmierć, skazują ludzi na życie. Light Yagami staje się więc reliktem brutalnie wkraczającym w uporządkowaną rzeczywistość, uzurpując sobie prawo do zmienienia jej według własnej wizji, którą uważa za najlepszą ${ }^{4}$.

Osoby popierające Kirę dają w ten sposób pozwolenie na powrót dawnych czasów, gdy prawo znajdowało się w rękach namaszczonego przez Boga władcy. Jego przeciwnicy buntują się przeciwko takiemu powrotowi do przeszłości, uznając go za nieprzystający do naszej rzeczywistości. Uważają oni, iż życie jest cenne, dlatego należy go bronić. Tu pojawiają się ważne kwestie: jak daleko należy pójść w obronie życia oraz czy w imię nowoczesnego świata można ścigać osobę, która, choć łamie jego zasady, także działa w jego obronie. Kira eliminuje przestępców, czyli osoby zagrażające bezpieczeństwu praworządnych obywateli, kierując się stworzonym przez siebie kodeksem etycznym. W wyniku takich działań ukazany zostaje najważniejszy wątek obcości, wprowadzony przez protagonistę mangi: odsłania się mocno zakorzeniony w społeczeństwach problem ambiwalencji etycznej.

Niejednoznaczne postawy w stosunku do głównego bohatera widać od samego początku historii, nawet wśród ludzi odpowiedzialnych za ściganie go. Jeden z bohaterów, policjant Tota Matsuda, mówi: „[...] chciałem tylko zauważyć, że w całym świecie, a zwłaszcza w Japonii, ilość przestępstw o charakterze brutalniejszym od zwykłego włamania znacząco spadła" (Obata, Ohba, 2007, s. 96). Nie należy traktować tego spostrzeżenia jako czegoś, co łagodzi wydźwięk mordów Kiry, bardziej byłoby to stwierdzenie pewnych, niepodważalnych faktów. $\mathrm{Z}$ kolei $\mathrm{w}$ kwestii otwartego popierania działań bohatera nikt już tak oficjalnie nie mówi, ponieważ wtedy byłby postrzegany jako osoba dająca pozwolenie na samosąd. Sytuacja staje się $\mathrm{w}$ takim przypadku niejednoznaczna: $\mathrm{z}$ jednej strony

3 Zaznaczenia wymaga, że pseudonim ten nadało mu społeczeństwo. Pochodzi on od angielskiego słowa killer, czyli „morderca”. Na temat dalszych implikacji, jeśli chodzi o zmianę imienia przez głównego bohatera, zob. G. Hammonds, K.A. Hammonds, 2017, s. 95-107.

4 Warto zauważyć, że sam notes ma funkcję alienującą, gdyż „zgubił” go Bóg Śmierci. Więcej na ten temat zob. S. Napier, 2010, s. 356-360. 
wyroki Kiry doprowadzają do znacznego spadku przestępczości, z drugiej zaś zabicie człowieka nadal jest zbrodnią. Następuje wyraźny podział społeczny zauważony przez samego Lighta. Podczas rozmowy z Bogiem Śmierci stwierdza:

Widzisz? Tacy właśnie są ludzie, Ryuk. Nie słyszałem, żeby na przykład na lekcjach wychowawczych w szkole przeprowadzano dyskusje na tematy typu „czy wolno zabijać złych ludzi?”. Ale gdyby takie pytanie zostało zadane, zapewne wszyscy udawaliby świętoszków, mówiąc „nie, nie, oczywiście zabijanie jest złe” i tak dalej. Oczywiście tak brzmi „poprawna” odpowiedź. I ludzie wiedzą, że takie właśnie poglądy powinni głosić w miejscach publicznych. Ale prawda o nich jest tutaj [w sieci - J.D.]. Z jednej strony boją się przyznać, że istnieję, a z drugiej - wierzą w „Kirę”, o którym ktoś, nie wiadomo nawet kto, napisał w Internecie. Nikt tego głośno nie mówi, ale wszyscy już wiedzą, że źli ludzie są przez kogoś likwidowani. Niewinni w głębi serca życzą Kirze powodzenia.

Obata, Ohba, 2007, s. 66-67

Light dostrzega hipokryzję ludzi, którzy dopiero w wirtualnym świecie wyrażają swoją prawdziwą opinię na temat działań Kiry. Szeroko pojęta poprawność polityczna „knebluje” społeczeństwo w mniejszym bądź większym stopniu, nie pozwala na wyrażenie prawdziwych przekonań, każe stwarzać pozory, grać niechciane role. Prawdziwe przekonania to coś, czego społeczeństwo boi się głośno wyartykułować. Dopiero pojawienie się obcego w postaci Kiry daje im odwagę, by wyrazić sprzeciw wobec takiego postępowania. Ludzie nie chcą być już ograniczani, lecz sami nie potrafią się wyzwolić z pęt myślenia narzuconego odgórnie, nie mogą wyartykułować swoich prawdziwych uczuć. Dopiero spotkanie z głównym bohaterem pozwala ludziom zbudować wewnętrzną harmonię, zobaczyć samych siebie. Powoli zaczynają także uzewnętrzniać własne „ja”. Józef Tischner pisał:

[...] doświadczenie spotkania, ściślej przeżycie spotkania, wprowadza tego, kto spotyka, w jakąś jedyną w swoim rodzaju osobistą prawdę spotkanego człowieka [...]. Spotykając, wiem, że inny człowiek jest, że jest wobec mnie takim, jakim jest naprawdę, bez masek i bez zasłon.

Tischner, 1980, s. 137

Protagonista dzięki szczerości swych czynów nie oszukuje ludzi, nie zakłada maski, w wyniku czego staje się dla społeczeństwa mniej obcy, bardziej swojski. Pomimo działania pod pseudonimem ma w sobie więcej z osoby, z którą drugi człowiek może czuć niemal braterską więź. Zaufa mu, a także powierzy swe pragnienie dotyczące wymierzania sprawiedliwości.

Skupienie władzy jedynie w dłoniach Kiry to jawny powrót do jednowładztwa, gdzie właśnie monarcha decydował o życiu i śmierci. Michel Foucault zauważał, że prawo to było głównym atrybutem panującego. Light, zyskując moc 
notesu, staje się Foucaultowskim suwerenem: „[...] twierdzenie, że suweren ma prawo życia i śmierci, znaczy w gruncie rzeczy, że może on skazywać na śmierć i pozwalać żyć [...]. Prawo suwerena jest więc prawem skazywania na śmierć i zezwalania na życie" (Foucault, 1998, s. 238). Główny bohater nagle przestaje być obcym, wręcz przeciwnie - staje się swoim. To osoba zdolna zrozumieć drugiego człowieka, a także odpowiedzieć na jego pragnienie dotyczące sprawiedliwości. Tu należy poczynić ważną uwagę: kontestując, w myśl Baumana, zastany ład, obcy zyskuje to znaczenie wyłącznie, jeśli chodzi o państwo i rządzące nim elity. Obywatele widzą w nim jednostkę potrafiącą zmienić rzeczywistość, wprowadzić nowe zasady i porządki, które sprawdzą się lepiej niż obecnie panujące prawa.

Bohater, co istotne, swoimi działaniami przywraca rytualizację śmierci oraz należną jej rangę. Jego sądy gromadzą mnóstwo widzów skupiających się teraz nie na rynku, lecz w Internecie, pełniącym współcześnie formę agory. Na bieżąco komentują oni wyroki Kiry, proponują, kto powinien zginąć, i chętnie uczestniczą w całym rytuale. Maciej Włodarski pisze: „[...] człowiek tamtych czasów chętnie patrzył na śmierć, zwłaszcza kiedy nie groziła ona jemu samemu. Publiczne egzekucje gromadziły mnóstwo ludzi żądnych uczestniczenia w tym swoistym misterium" (Włodarski, 1987, s. 8). To pokazuje, iż społeczeństwo, mimo oficjalnego odżegnywania się od dawnych zwyczajów, nadal chce uczestniczyć w takich wydarzeniach, będących czymś niezwykłym, mistycznym. Biorąc udział w rytuale śmierci, mogą poczuć, jaką moc ma Kira, i współuczestniczyć w wydawanych przezeń wyrokach. Internetowe fora są średniowiecznym rynkiem, a rozmowy o kolejnych morderstwach - oglądaniem spektaklu śmierci. Działania protagonisty zyskują coraz mocniejszą rangę swojskości, on sam z kolei wyrasta na kogoś, kto pozwala im patrzeć, jak uprzywilejowana jednostka odbiera życie. Przywrócone przez Kirę publiczne egzekucje zaspokajają potrzebę zemsty ludzi na tych, którzy występują przeciwko prawu czy ustalonym normom. Dzięki bohaterowi obywatele znowu zaczynają wierzyć $\mathrm{w}$ istnienie sprawiedliwości.

Negatywne uczucia społeczeństwa względem czynów protagonisty byłyby w takim wypadku czymś złudnym. Pragnie ono silnej, zdecydowanej jednostki karzącej przestępców, dlatego też mieszkańcy różnorakich państw nie postrzegają Kiry w kategorii mordercy, wichrzyciela. Tu należy się zastanowić, co powoduje, iż na samym początku historii stał się kimś nieakceptowalnym dla części świata, osobą przeznaczoną do wyeliminowania, by nie niszczyła ukształtowanej w ostatnich dekadach wspólnoty wartości. Odpowiedź mogłaby być następująca: społeczeństwo po XIX wieku odrzuciło model władcy absolutnego, kierując się w stronę demokracji. Zasady państwa prawa zabraniają samosądów, zabijania przestępców, każdemu przysługuje prawo do sprawiedliwego procesu. Jednocześnie, co dostrzegają obywatele, dogmaty społeczeństwa demokratycznego nie dają im poczucia bezpieczeństwa. W mandze wyraźnie zostaje za- 
akcentowany fakt, że gdyby ludzie mieli pewność, iż sprawiedliwości stało się zadość, nie popieraliby Kiry. Zostałby uznany za szaleńca, który usilnie próbuje poprawić dotychczasową strukturę. Poparcie, jakiego udziela mu duża część mieszkańców różnych krajów, dowodzi, że system demokratyczny nie działa wystarczająco sprawnie i wymaga poprawy.

W tomie dziewiątym Death Note wiceprezydent Stanów Zjednoczonych deklaruje, że rząd zaprzestaje ścigania bohatera. Mówi przy tym: „[...] dzięki Kirze ustały wojny, a organizacje przestępcze na całym świecie stoją na skraju unicestwienia" (Obata, Ohba, 2009, s. 101). Pyta także zgromadzonych dziennikarzy, „czy ktoś [...] jest w stanie całkowicie zanegować to, co robi Kira?" (Obata, Ohba, 2009, s. 102). Trzeba tu zwrócić uwagę na słowo „zanegować”. W przypadku protagonisty mowa o wartości jego działań. Dzięki egzekucjom przestano prowadzić wojny, spadła przestępczość. Tę wartość daje Kira i tych faktów dotyczy pytanie wiceprezydenta: czy ludzie mogą zanegować, że świat przedstawiony w mandze stał się lepszy? Pomimo niezaprzeczalnego faktu, że nie przystaje do obecnych mu czasów, pomaga on ludziom w zredefiniowaniu reguł rządzących rzeczywistością. Protagonista sprawia, że zanikają przejrzystość oraz czytelność świata, nasuwają się wątpliwości. Niezgoda bohatera na brak zmian ośmiela innych. Zaczynają głośno wyrażać własne zdanie o otaczającym świecie i obowiązujących w nim zasadach, które to, jak się okazuje, należy podać w wątpliwość.

Przywoływany już wcześniej Tota Matsuda, mówi:

Czy z punktu widzenia zwykłych, dobrych ludzi... świat nie stał się lepszym miejscem dzięki Kirze? [...] Chcę tylko powiedzieć, że rozumiem tych, którzy uważają go za mesjasza... Ja też jestem tylko zwykłym, słabym człowiekiem... Dlatego ich rozumiem! [...] Ścigam Kirę, nie będąc przekonanym, że jest złem absolutnym...

Obata, Ohba, 2009, s. 106

Kirę ścigają policja, FBI, specjalna grupa pod dowództwem superdetektywa. Osoby te łączy to, że mają odpowiednie zdolności pozwalające im stawić czoła przestępcom. Takiej siły nie dają zwykli obywatele. Potrzebują oni pomocy, dlatego też popierają Kirę. Główny bohater zapewnia im poczucie bezpieczeństwa, otacza parasolem ochronnym. Przy okazji osądów podważa kompetencje silnych do sprawowania władzy, a na coś takiego nie ma z ich strony przyzwolenia. Można stwierdzić, że Kira mówi władzy, iż ta jest zbędna i teraz to właśnie on będzie bronił słabszych.

Warto też bardziej wczytać się w wypowiedź Matsudy. Pokazuje ona swoistą bezradność człowieka rozdartego pomiędzy państwem a społeczeństwem. Jako policjant, pełni funkcję osoby reprezentującej państwo, powinien więc z całą mocą ścigać Kirę i być przekonany, że racja leży po stronie państwa. Tymczasem żyjący w nim obywatel dostrzega pozytywne skutki działań głównego bo- 
hatera. Sam Matsuda uznaje siebie za słabego (!) człowieka, także obawiającego się o własne życie (będąc policjantem, jest o wiele bardziej narażony na niebezpieczeństwo). Rozumie więc postawę społeczeństwa, dostrzega to, co wyraźnie umyka państwu. Chodzi tu o większe poczucie bezpieczeństwa i sprawiedliwości wśród obywateli. Tota potrafi myśleć nie tylko jako przedstawiciel państwa, lecz również zwykły obywatel. Ten wyraźny, wewnętrzny dwugłos najsilniej wyraża ambiwalencję wobec zachowania protagonisty.

Tu trzeba przytoczyć ważną wypowiedź Lighta o działaniach Kiry:

Light: nie do nas należy oceniać, czy Kira jest zły czy dobry [...]. Naszym zadaniem jest po prostu go schwytać. Możliwe, że gdy to zrobimy, świat pogrąży się w chaosie... Ale to bez znaczenia. Dobro... Zło... Wszystko zależy od końcowego efektu. Jeśli go schwytamy, Kira będzie złem. Jeśli uda mu się podporządkować świat - będzie dobrem.

Aizawa: więc... dobrzy będą ci, którzy zwyciężą?

Ide: w sumie... jak się zastanowić, to zawsze tak było.

Obata, Ohba, 2009, s. 108-109

Podążając takim tropem, dochodzi się do wniosku, że celem działań głównego bohatera, prócz oczyszczenia świata z przestępców, byłaby zmiana postrzegania jego czynów. Jeśli zostanie schwytany, okaże się złym - obcym, jeśli to on zwycięży, będzie dobrym - swoim. Walka toczy się o uznanie „obcości” za „swojskość, a co za tym idzie - zredefiniowanie ustalonych praw, norm czy zachowań etycznych przyjętych przez wspólnotę.

Stopniowo zaczyna także wzrastać liczba osób popierających sposób działania Kiry:

Lato 2009. Likwidowanie przestępców w wykonaniu Kiry zaczyna przybierać na sile. Opinia publiczna na całym świecie jest przerażona, choć coraz więcej osób po cichu deklaruje poparcie dla działań Kiry. Z czasem ich głos staje się coraz bardziej słyszalny. Wreszcie dochodzi do sytuacji, w której nie tylko poszczególne jednostki czy grupy, ale i państwa zaczynają otwarcie popierać Kirę. Obata, Ohba, 2008, s. 164-165

Przytoczony opis, pokazujący wizję świata rządzonego przez Kirę, prowadzi do konkluzji, że jego działania, choć bezprawne, przynoszą pozytywne rezultaty. Zapewnił on bezpieczeństwo nie tylko grupom, ale wręcz narodom, dał poczucie, że każdego przestępcę spotka kara. Jakiekolwiek próby negacji jego czynów, odwoływanie się do wartości demokratycznych w konfrontacji z rezultatem prowadzonych przez niego sądów wydają się ludziom mało poważne. Nie zaprzeczają, iż rządy Kiry doprowadziły do autorytaryzmu, lecz jednocześnie widzą znaczącą poprawę bezpieczeństwa. Gdy bohater umiera, wszystko wraca do dawnego stanu, co dostrzegają nawet ścigające go osoby. To pokazu- 
je, iż również oni przyznają, że działania protagonisty miały pozytywny wpływ na obywateli.

Istota sensu śmierci

Jean Baudrillard o śmierci, która nie jest śmiercią naturalną, pisał w następujący sposób:

Z jakiegoś powodu [...] gwałtowna i przypadkowa śmierć, którą niegdysiejsze wspólnoty uważały za bezsensowną [...], zyskała dla nas aż tak wielkie znaczenie. Tylko o niej się mówi, tylko ona budzi fascynację, tylko ona porusza naszą wyobraźnię [...]. Czy jest to wyraz obrzydliwego żerowania mediów na śmierci? Nie, te jedynie wykorzystują fakt, że jedynymi wydarzeniami, które zachowują jeszcze dla nas jakieś bezpośrednio uchwytne, niewypaczone i niezmanipulowane znaczenie, są te, w które w ten czy inny sposób uwikłana jest śmierć.

Baudrillard, 2007, s. 210-211

Wyroki Kiry prowadzą do „bezsensownej” śmierci eksponowanej w mediach. Oddziałują one na wyobraźnię nie jednostki, lecz społeczeństwa, zaspokajając potrzeby uczestnictwa $\mathrm{w}$ spektaklu śmierci. Obywatele pragną zobaczyć śmierć wymykającą się logice (nikt nie wie, JAK zabija Kira), racjonalnemu pojmowaniu. Spełnieniem takiego pragnienia są wyroki wykonywane przez protagonistę. Przestępca staje się zakładnikiem Kiry, a tym samym - śmierci. Zostaje on skazany na nieustanne wyczekiwanie, niepewność, strach. Nie wie, kiedy nastąpi moment, gdy śmierć w postaci Kiry o niego się upomni. Ma on nie znać dnia ani godziny, żyjąc w nieustannym napięciu. To z kolei służy zaspokojeniu społecznego pragnienia, by przestępca przed swoim zgonem cierpiał w równym stopniu, co ofiara. Chce się mu zadać ból nie przez śmierć, lecz tortury stricte mentalne. Samo zabicie go wskutek wpisania do notesu byłoby niczym innym, jak wyrazem łaski.

Tu warto zwrócić uwagę na wyroki wykonywane przez bohatera. Jedna $\mathrm{z}$ reguł notesu brzmi: „[...] po wpisaniu imienia i nazwiska w ciągu 40 sekund czasu ludzkiego należy podać oczekiwaną przyczynę śmierci. Jeśli przyczyna śmierci nie zostanie opisana, osoba ta umrze na zawał. Po wpisaniu przyczyny śmierci piszący otrzymuje kolejne 6 minut i 40 sekund na dokładne opisanie jej okoliczności” (Obata, Ohba, 2008, s. 13). Light mógł więc torturować tych, którzy popełnili ciężkie zbrodnie, ale tak nie zrobił. Wpisując wyłącznie same nazwiska, komunikuje światu, że pojawił się ktoś, kto wymierza jedną, a zarazem równomierną karę zbrodniarzom. Zabijanie wskutek zawału ma stanowić ogłoszenie, że oto przybyła osoba przeprowadzająca sąd nad ludzkością. Wyroki Kiry mia- 
łyby więc w sobie szczególną dwoistość: wymierzanie sprawiedliwości, a także służenie zaspokojeniu ludzkiej potrzeby śmierci gwałtownej, nienaturalnej, wykraczającej poza ustalony porządek świata. Stąd wynika takie poparcie dla Kiry: społeczeństwo chce chleba i igrzysk, a to zapewnia im główny bohater 5 .

Jak wspomniano, protagonista to Foucaultowski suweren mający władzę nad życiem i śmiercią. Sama kara śmierci ulegała w ciągu wieków systematycznej zmianie, z czasem zaczęto uważać ją za niehumanitarną i nieekonomiczną. Zamiast zabijać zbrodniarzy, lepiej posłać ich na przymusowe roboty. Należy również mieć szacunek do życia, jakiekolwiek by ono było. Działania Kiry zaburzają ustalone przez rządzących prawa, w wyniku czego następuje swoisty zwrot ku przeszłości. Bohater pokazuje społeczeństwu, że kara śmierci, pomimo nieekonomiczności, nadal jest potrzebna i ma sens. Swoimi działaniami wydobywa z ludzi ukrytą tęsknotę, by władza ostateczna spoczywała w ręku jednej, wybitnej jednostki. Kara śmierci w wykonaniu Kiry, pomimo jednostajności (śmierć wskutek zawału), nosi wszelkie znamiona śmierci, jaka jeszcze potrafi kogokolwiek zainteresować. Jej gwałtowność, nieuchronność, a przy tym wielka niewiadoma wywołują w zwykłym człowieku podniecenie, sprawiają mu rozkosz. Uczestnictwo $w$, zdawałoby się, wypędzonym przez demokratyczną władzę spektaklu śmierci daje obywatelom szeroko pojęte spełnienie. Jest to spełnienie oparte na potrzebie posiadania władzy nad życiem drugiego człowieka. Wydaje się ono umotywowane pragnieniem sprawiedliwości, jednak w rzeczywistości ludzie ci stają się czynnymi uczestnikami masowych egzekucji dokonywanych przez Kirę. Dzięki temu mogą zaspokoić potrzebę uczestniczenia w takich właśnie spektaklach śmierci. Mogłoby się więc wydawać, że społeczeństwa popierające Kirę są barbarzyńskie i kierują się wyłącznie żądzą zemsty należną ludziom w dawno minionych czasach. Tymczasem Baudrillard zapytuje, czy właśnie w taki sposób nie oddajemy tamtym ludziom czci: „[...] zemsta zakłada bowiem nadal śmiertelną wzajemność, nie jest prymitywna, nie jest czystą naturalna żądzą [...]. Jest wyrafinowaną formą zobowiązania i wzajemności - formą symboliczną" (Baudrillard, 2007, s. 224).

Zemsta to uczucie towarzyszące ludzkości od zarania dziejów. Wcześniej to monarcha dokonywał rozrachunku z tymi, którzy popełnili zbrodnię. Władza w XIX wieku odebrała mu to prawo, wypędziła poza obręb zdrowego i szlachetnego społeczeństwa, uznając je za coś złego, nieprzystającego do humanitarnych czasów (stąd też zawziętość osób ścigających Kirę). Wynika ona z faktu, że, jak twierdzi Baudrillard, „śmierć i przemoc, wymykające się monopolistycznej władzy państwowej, zyskują wywrotowy charakter - wieszczą obalenie władzy" (Baudrillard, 2007, s. 227). Te słowa komponują się więc z tezą Baumana. Dzia-

${ }^{5}$ Egzekucje Kiry są eksponowane w mediach, szczególnie w telewizji. Widzi ona w nich szansę na zwiększenie oglądalności swoich kanałów. Przykładem może być Sakura TV, gdzie jeden z reżyserów otrzymuje wiadomość od „Kiry”, którą ma zaprezentować widzom. Zamiast strachu wywołuje w nim ekscytację, ponieważ dzięki temu program może stać się hitem sezonu. 
łania Kiry - obcego nieuchronnie prowadzą do rewolucji mającej na celu zmianę całego systemu, praw i reguł etycznych. Naturalnie, $\mathrm{z}$ jednej strony na coś takiego rządzący nie wyrażą zgody, przynajmniej w Japonii, gdzie bohater działa najintensywniej, z drugiej zaś - „dochodzi do sytuacji, w której nie tylko poszczególne jednostki czy grupy, ale i państwa zaczynają otwarcie popierać Kirę" (Obata, Ohba, 2008, s. 165). Prawo do kontroli nad życiem i śmiercią zostaje w niektórych krajach powierzone Kirze, co wywołuje uczucie konsternacji, niepewności, lecz najbardziej - ambiwalencji. Człowiek nie potrafi sobie wyobrazić, iż jakiekolwiek państwo może przekazać jedno z odwiecznych praw w ręce jednej osoby, ale przy tym rodzi się w nim pewność, że dzięki temu dokona się zemsta na tych, którzy w sposób systematyczny niszczą tkankę społeczną. Ludzie są gotowi oddać życie swoje i innych w dłonie protagonisty, gdyż instynktownie czują, że ten nie zawiedzie ich oczekiwań w kwestii sprawiedliwości.

\section{Zakończenie}

Dotychczasowe rozważania mogą prowadzić do następującej konkluzji: Kira żąda od całego społeczeństwa zrobienia rachunku sumienia, przewartościowania ustalonych praw. Dzięki swojej „obcości” widzi, że nie sprawdzają się one $\mathrm{w}$ zderzeniu z ukrytymi pragnieniami jednostki. Pomimo bycia kimś, kto nie przystaje do współczesnych mu czasów, część obywateli uznaje go za jednostkę pożądaną, wręcz niezbędną. W wyniku jego działalności coraz więcej ludzi ma odwagę głośno mówić o dręczących ich problemach związanych z niedostatkiem sprawiedliwości, potrzebą wymierzenia winnym kary. Decyzje protagonisty mimo swej amoralności pozwalają ludziom zrozumieć, iż ci w głębi serca pragną, by Kira ciągle istniał oraz nie zaprzestał swych sądów. Stanowi on swego rodzaju dopełnienie człowieka, bez którego ten nie byłby w stanie przyjąć określonej postawy wobec rzeczywistości. Bohater pomaga społeczeństwu w nieustannym poszerzaniu posiadanej wiedzy o nich samych. Fakt bycia obcym, mimo negatywnych konotacji tej figury, pomaga wspólnocie $\mathrm{w}$ zredefiniowaniu wyznawanych przez nią wartości. Pojawienie się obcego powoduje, że niektórzy obywatele zaczynają podejmować dyskusję z dotychczasowymi prawami, żądają także ich zmienienia. Z jednej strony Kira niszczy porządek świata, z drugiej pomaga $w$ samopoznaniu oraz zdefiniowaniu się człowieka. Protagonista, opierając się na znajomości ludzkiej natury, wykorzystuje dwa niezależne obszary: pragnienie sprawiedliwości oraz hipokryzję, by w ten sposób zaangażować społeczeństwo w swoje działania. Tym samym, co jest niezwykle ważne w kontekście interpretacji działań Lighta, dotychczasowa opozycja swój - obcy ulega zatarciu i staje się niejednoznaczna.

Główny bohater jest więc kimś, kto zmusza ludzi do ciągłej reinterpretacji tego, co do tej pory wydawało się trwałe, absolutne, nie podlegało żadnej dys- 
kusji. Podejmując takie działania, są oni w stanie odkryć inny wymiar prawd, jakie wśród nich panują. Zaczynają je podważać, także odrzucać, gdy te nagle okazują się niewystarczające i przebrzmiałe. Kira, negując suwerenność jednego tylko punktu widzenia, rozwija dotychczasowy horyzont doświadczeń jednostki. Według Marka Szulakiewicza, obcy wkracza gwałtownie w dotychczas uporządkowany świat i domaga się od obywateli spojrzenia na rzeczywistość jego oczyma, chcąc tym samym przyjęcia zupełnie innej perspektywy (Szulakiewicz, 2006, s. 80-83). Tym samym obywatel musi dokonać prostego na pozór wyboru: albo odrzuci Kirę i prezentowany przez niego system, a tym samym zaakceptuje obecną rzeczywistość, albo uzna działania protagonisty za słuszne, w wyniku czego dojdzie do przewartościowania panującego prawa. Przedstawiona historia pokazuje, iż taka decyzja wcale nie jest tak łatwa, jak mogłoby się zdawać.

\section{Literatura}

Baudrillard J., 2007, Wymiana symboliczna i śmierć, Królak S., przeł., Warszawa.

Bauman Z., 2000, Ponowoczesność jako źródło cierpień, Warszawa.

Dąbrowski M., 2001, Swój/Obcy/Inny. Z problemów interferencji i komunikacji międzykulturowej, Izabelin.

Foucault M., 1998, Trzeba bronić społeczeństwa. Wykłady w College de France, 1976, Kowalska M., przeł., Warszawa.

Grabias S., 2013, Analityczne kategorie obcości, „Studia Socjologiczne”, nr 1 [b.n.s].

Hammonds G., Hammonds K.A., 2017, Seeing with Shinigami Eyes: Death Note as a Case Study in Narrative, Naming, and Control, „The Phoenix Papers”, vol. 3, no. 1, s. $95-107$.

Napier S., 2010, Death Note: The Killer in Me Is the Killer Is You, in: Lunning F., ed., Mechademia, Minneapolis, s. 356-360.

Obata T., Ohba T., 2007, Death Note, Dybała P., przeł., t. 1, Szczecin.

Obata T., Ohba T., 2008, Death Note, Dybała P., przeł., t. 7, Szczecin.

Obata T., Ohba T., 2009, Death Note, Dybała P., przeł., t. 9, Szczecin.

Simmel G., 2006, Most i drzwi, Łukasiewicz M., przeł., Warszawa.

Szulakiewicz M., 2006, Dialog i metafizyka. W poszukiwaniu nowej filozofii pierwszej, Toruń.

Tischner J., 1980, Bezdroża spotkań, „Analecta Cracoviensia” 12, s. 137-172.

Waldenfels B., 2002, Topografia obcego. Studia z fenomenologii obcego, Sidorek J., przeł., Warszawa.

Włodarski M., 1987, Ars moriendi w literaturze polskiej XV i XVI w., Kraków.

Znaniecki F., 1990, Współczesne narody, Dulczewski Z., przeł., Warszawa.

Jarosław Dobrzycki - doktorant w Instytucie Literaturoznawstwa Uniwersytetu Śląskiego w Katowicach. Zajmuje się szeroko rozumianą literaturą i kulturą popular- 
ną. Korzystając z różnorakich metodologii humanistycznych, stara się na nowo odczytać teksty popkultury, wskazując przy tym inne drogi, którymi można podążać podczas interpretacji tychże utworów. Jego zainteresowania oscylują wokół zagadnień medioznawczych oraz socjologicznych.

e-mail: jaroslaw.dobrzycki7@wp.pl 